University of South Carolina

Scholar Commons

2011

\title{
Mechanical Characterization of Polymer Electrolyte Membrane with Optical Methods
}

\author{
Xinyu Huang \\ University of South Carolina - Columbia, xyhuang@sc.edu \\ Luis Alva \\ Jay Neutzler \\ University of South Carolina - Columbia, neutzler@email.sc.edu
}

Follow this and additional works at: https://scholarcommons.sc.edu/emec_facpub

Part of the Energy Systems Commons, Manufacturing Commons, Membrane Science Commons, and the Polymer Science Commons

\section{Publication Info}

Postprint version. Published in ECS Meeting Abstracts, Issue 909, 2011.

(C) ECS Meeting Abstracts, 2011, The Electrochemical Society

Huang, X., Alva, L., Neutzler, J. (2011). Mechanical Characterization of Polymer Electrolyte Membrane with Optical Methods. ECS Meeting Abstracts, 909.

This Article is brought to you by the Mechanical Engineering, Department of at Scholar Commons. It has been accepted for inclusion in Faculty Publications by an authorized administrator of Scholar Commons. For more information, please contact digres@mailbox.sc.edu. 


\section{Mechanical Characterization of Polymer Electrolyte Membrane with Optical Methods}

\author{
X. Huang, L. Alva, J. Neutzler \\ University of South Carolina \\ Mechanical Engineering Department \\ Columbia, SC 29208
}

Mechanical properties of polymer electrolyte membrane have important implications in the endurance of many electrochemical energy conversion devices [1]. Mechanical experiments are effective method to reveal discrete damage developed in the membrane by quantifying the change of mechanical strength and toughness. Regular strain measurement methods are overly intrusive to the thin and relatively fragile polymer electrolyte membrane; hence optical-based minimal invasive stress/strain measurement methods are studied.

The authors have utilized non-contact optical methods to characterize the mechanical properties of the Nafion ${ }^{\circledR}$ membrane, a perfluorosulfonic acid membrane widely use in fuel cells, electrolyzers, flow batteries, and artificial muscles. The mechanical test system was set up on an optical bench, as shown in Figure 1. The load is applied to the sample with two actuators driven by stepper motors controlled by a LabView program. The sample is enclosed in an environmental chamber with wellcontrolled temperature and relative humidity $(\mathrm{RH})$. Photoelasticity and digital image correlation (DIC) methods are implemented to capture real-time full-field stress-strain state of the polymer membrane. Photoelasticity method relies on the birefringent properties of the membrane, it can only be applied to transparent membrane without electrode. The DIC method relies on a surface contrast pattern to measure the strain distribution, it is applicable to coated or painted samples.

With this system, the temperature- and RH-and rate-dependent mechanical properties of polymer electrolyte membrane are studied. Representative test results are shown in Figure 2 and 3. With the real-time full-field stress-strain distribution information, the effect of defect morphology and orientation on the membrane failure can be clearly visulized.
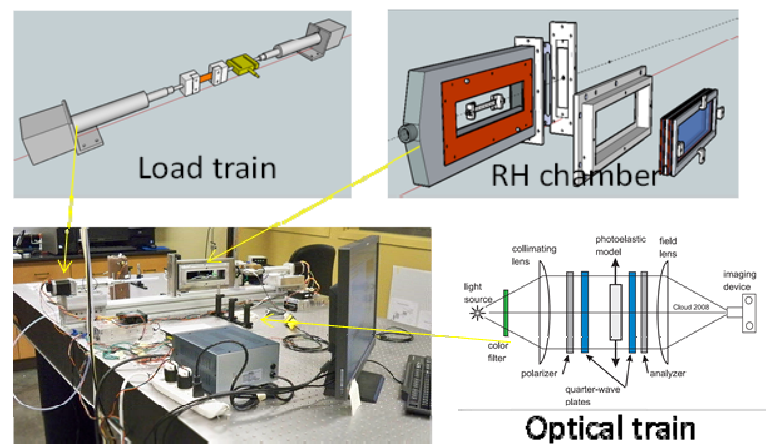

Optical train

Figure 1. Mechanical test system for polymer electrolyte membrane.
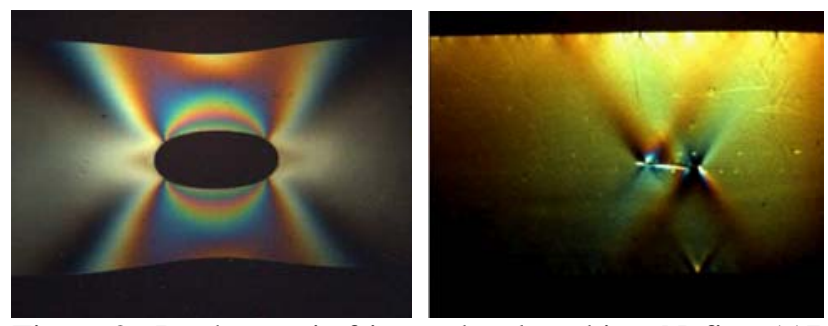

Figure 2. Isochromatic fringes developed in a Nafion-117 membrane with a center hole (left) and with a sharp crack (right) under tensile loading.

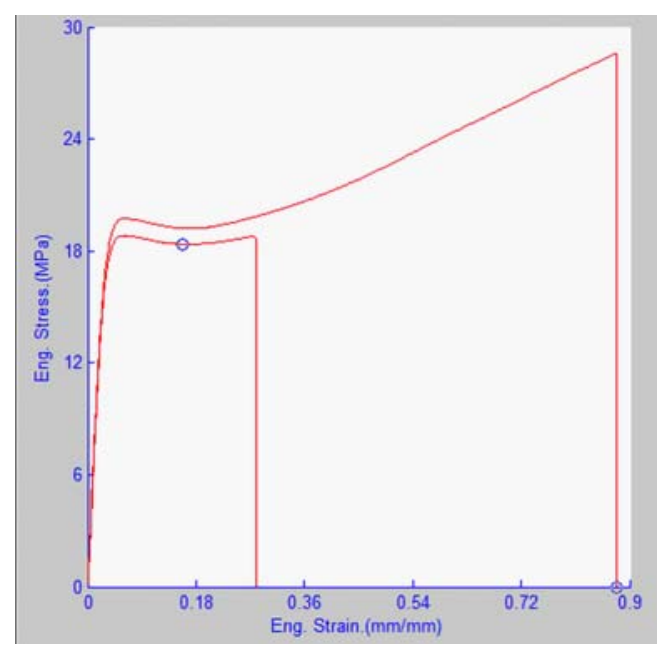

Figure 3. Stress-strain curves of Nafion-117 membrane containing cracks of two different orientations.

References:

[1] X. Huang, R. Solasi, Y. Zou, K. Reifsnider, D. Condit, S. Burlatsky, T. Madden, "Mechanical endurance of polymer electrolyte membrane and PEM fuel cell durability,” Journal of Polymer Science, Part B: Polymer Physics, Vol 44, 2006, 2346-2357. (29) 